Article

\title{
Indefinite Article + Possessive + Noun in Spanish: A Case of Refunctionalization?
}

\author{
Enrique Pato $\mathbb{D}$
}

Département de littératures et de langues du monde, Université de Montréal, Montréal, QC H3C 3J7, Canada; enrique.pato-maldonado@umontreal.ca

Received: 9 October 2018; Accepted: 14 November 2018; Published: 19 November 2018

\begin{abstract}
The phenomenon under discussion is an example of a grammatical change that can be explained by refunctionalization, and as such, can be understood as the acquisition of a new meaning by an 'endangered' grammatical construction, which is reassigned to express another value. Refunctionalization involves the development of a new function (in this case a syntactic-semantic one). When an item loses its function, or is marginal within a system, it can be lost (as happens with the construction under study in Standard Spanish), it can be 'saved' as a marginal element (as in some areas of American Spanish varieties) or it can be reused for other purposes (as in the Central American Spanish varieties). The latter case presents new discursive values. Hence, this construction should be understood as an example of reusing grammatical functionally opaque material for new purposes.
\end{abstract}

Keywords: Spanish; syntax variation; <indefinite article + possessive + noun $>$ construction; refunctionalization

\section{Introduction}

Naming and classifying grammatical phenomena is useful for acquiring a better understanding of them. Theory may help us understand better the phenomenon we are studying, but what claims for a more or less far-ranging theory is the occurrence of the construction itself. The Spanish linguistic construction <indefinite article + possessive + noun> (e.g., un.MSG su.M/FSG/PL amigo.MSG 'a his/her/their friend'), has been awakening a fair amount of interest, at least in the last two decades.

Refunctionalization (or exaptation) is a specific kind of adaptation (Heine 2003; Norde 2009). Briefly, exaptation happens when a grammatical form $G_{1}$ derives from a form without grammatical meaning $\mathrm{G}_{0}$ (less grammatical). Adaptation happens when a grammatical form $\mathrm{G}_{1}$ derives from a more grammatical form $G_{2}$. We define the notion of refunctionalization (or exaptation) as the process in which a grammatical element, which is close to disappearing, acquires a new 'meaning', and is eventually relocated within the grammatical system in order to express another value or another function. Adfunctionalization (or capitalization), on the other hand, is the addition of a new value to the already existent meaning/function of an element. Both processes help us understand better how grammatical material is formed and maintained within languages and they also help us 'name' the construction under discussion ('un su amigo'). ${ }^{1}$

Refunctionalization can take place when a grammatical form loses almost all its original semantic content and is newly employed as a semantically distinct form ('reanalysis of function' à la Heine 2003). It happens also when the item in question does not have a function (i.e., 'linguistic junk'), although it

1 Other terms that have been employed are exaptation (Lass 1990, 1997; Norde 2002; Vincent 1995), capitalization (Pountain 2000), regrammaticalization of desemanticized forms (Greenberg 1991), functional renovation of old forms (Brinton and Stein 1995), degrammaticalization (Heine 2003; Norde 2002, 2009), hipoanalysis (Croft 2000), etc. These different terms illustrate the terminological confusion that exists, since they do not refer to different types of change (Narrog 2007). 
might not necessarily be totally 'junk' (Lass 1990). The target of exaptation may be an already existent category (Traugott 2004). In contrast to the typical processes of grammaticalization, refunctionalization can be a discontinuous change (or 'a jump', Giacalone Ramat and Hopper 1998; Smith 2011). The cases in which the meaning of a construction is displaced to a specific context are also considered instances of exaptation (like 'un su amigo').

Interestingly, the apparition of a certain phenomenon can be both the result of refunctionalization and of adfunctionalization: for instance, it might be due to refunctionalization for one specific variety $X$ (e.g., Central American Spanish), and due to adfunctionalization for another variety Y (e.g., Historical and Standard Spanish). The 'obsolete' material may be lost or might be used again in order to express an existent grammatical category, or in order to encode a brand new category.

The whole process is related to the development of morphological material that is difficult to acquire - it is this inadequate acquisition that enables the possibility of reanalysis for that trait (Willis 2016).

The main purpose of this paper is to demonstrate that <indefinite article + possessive + noun $>$ construction in Central American Spanish can be explained as a case of refunctionalization.

\section{Application of the Term and Interest in the Construction}

The main question is whether the history of the 'un su amigo' construction-as a process of grammatical change-can be explained by refunctionalization (or exaptation). As previously stated, exaptation implies the development of a new function which, in this case, would be both syntactic and semantic. When an element loses its function or it becomes marginal within a system, it may either disappear (which is what has happened with the 'un su amigo' construction in Standard Spanish), survive as a marginal element (as in some areas of American Spanish varieties like Northern Argentina) or it might be used anew for other communicative purposes (as in South Mexico and Central America varieties). This construction is an example of reutilization of functionally opaque grammatical material for new purposes. The aforementioned construction would have been assimilated into the vocabulary as a starting point to exaptation.

The stages involved in this paper deal with the history of the Spanish language (both Historical and Standard Spanish and Central America varieties) and the different values of the construction.

It is crucial to note that the exaptated construction shows 'conceptual novelty' - the speaker analyzes a semantic property found in the context as an inherent property of the lexical unit (Croft 2000). Exaptation is distinct from grammaticalization inasmuch as, in the latter, a lexical element acquires a grammatical function and suffers formal changes within this process, while, in the former, an old and fading grammatical form is retained and assigned a new function (Vincent 1995).

Exaptation and grammaticalization are both based on reanalysis and lead to the formation of grammatical elements-the difference lies in the direction of the process. The reasons for these processes have to be looked for in the communicative needs of the speakers and most of the time can be traced to a tendency to gain clarity of expression. These phenomena produce both an enrichment of the available discursive tools and a progressive grammaticalization of new values within new contexts (Company Company, Concepción 2005), as will be seen see in Section 4. Referential values are weakened, while textual and discursive values end up strengthened.

At least two general questions have determined the interest in the study of this construction:

(1) Is it a case of syntactic borrowing? The answer is no, since it is not documented exclusively in areas with either a strong indigenous language influence or a high index of bilingual speakers. García Tesoro (2011, p. 206), in the only work that has been concerned with Maya speakers, demonstrates that the structure under study "shows itself with a similar frequency of utilization both in monolingual and bilingual speakers" (author's translation).

(2) Is the value in medieval and modern Spanish the same? The answer is also no-a new communicative purpose is attested in modern Spanish (Central America varieties). As we know, possession is culturally determined; it is a 'biocultural' domain (Carlson and Payne 1989; Seiler 1983). Nowadays, it is the appreciation that the speaker makes of a specific situation that determines the use of the 
construction, which places the possessee on focus and marks it as a relevant syntactic constituent: a pragmatically and perceptively relevant entity. That is, the construction moves from a textual meaning to a discursive meaning (Company Company, Concepción 2005; Palacios Alcaine 2004) as we will see.

\section{Some Remarks about the Construction}

As we know, the 'un su amigo' construction is an overspecified structure that conveys the value of inherent possession, that is, in which 'the owned cannot be thought of without the owner'. Recalling previous studies, Pato $(1999,2002)$, García Tesoro $(2002,2011)$, Palacios Alcaine (2004), Nieuwenhuijsen (2005, 2007), and Company Company, Concepción (2005, 2009), the construction:

- Is documented in all Mesoamerica, from Southern Mexico to Panama.

- Is not a stigmatized construction in those varieties.

- Is not a trait exclusive to popular level.

- Is neither exclusive nor specific of indigenous (autochthon) speakers.

- Is part of the standard register within Central American Spanish.

- May be explained without having to appeal to 'contact' or 'convergence' between Spanish and Maya languages (Company Company, Concepción 1995, 2005; Martin 1985; Pato 2002).

- There are not studies that have delimited its sociolinguistic profile (and the differences within the different communities) yet cf. (Pato 2002).

- Is attested throughout the whole history of the Spanish language.

On the other hand, its frequency within the corpuses we have consulted or compiled is extremely variable. For example, there are 1149 cases (from 13th to 16th centuries) in CORDE (Corpus diacrónico del español) and 52 cases (30 of them in Guatemala and 11 in Mexico) in CREA (Corpus de referencia del español). García Tesoro (2002) works with 81 cases from interviews (Guatemala); Palacios Alcaine (2004) works with 60 literary cases from Guatemala, El Salvador, and Honduras; Nieuwenhuijsen (2005) uses 629 cases from Corpus del español (339 of them from the 16th century); Silva Ceceña (2005) studies 252 cases; Company Company, Concepción $(2005,2009)$ analyzes 97 cases (in a primary corpus) and 96 from narrations and interviews of Central American indigenized Spanish (Chiapas and Guatemala); Nieuwenhuijsen (2007) found 173 examples within the press of Guatemala («La Hora») and Mexico («La Jornada»); and Elsig (2015) used 120 examples from the PRESEEA Guatemala Corpus. The data regarding frequency is relevant to support general conclusions about the construction.

The construction has been very well defined in previous works. The following is just a brief résumé. We know that its extension went from masculine to feminine ('un su > una su'), from singular to plural ('un su $>$ unos sus'), and apparently from 3rd person to 1st and 2nd person. Nieuwenhuijsen (2007) indicates that the instances in the 3rd person are the most numerous, Company Company, Concepción (2009) finds the same tendency (up to 86\%), and Pato (2002) concurs. The construction also changed from introducing an entity and delimitating it (with reference to other similar entities) to introducing topical and important entities that are going to subsist within the discourse. It also extended from [+human] nouns to [-human] nouns, that is, it has suffered a semantic demarcation (Company Company, Concepción 2005, 2009; Nieuwenhuijsen 2005; Palacios Alcaine 2004; Pato 2002).

Moreover, its use can be 'measured' in informational and argumentative terms. First of all, the use of this construction motivated by the context, i.e., the $<$ indefinite article + possessive + noun $>$ construction acts as an emphasizer of narrative discourse, as will be seen in the following section. The construction also acquires a textual meaning (discursive value), dependent on the discourse and independent from the external situation. 


\section{Different Values of Indefinite Article + Possessive + Noun Construction}

\subsection{Partitive Value}

The main meaning of this construction is 'one of/among several', which is attested since Medieval Spanish (Company Company, Concepción 2005; Keniston 1937; Palacios Alcaine 2004; Pato 1999, 2002; Serradilla Castaño 2007). It appears with [+human] nouns in Medieval Spanish (cf. 1a), and also in Central America varieties (cf. 1b Costa Rica, 1c Guatemala, 1d Belize):

(1) a. El lombardo adoleçió de dolençia mortal, et un su amigo que había, desque lo vio en la muerte, consejol que se confesase en Sancto Domingo [D. Juan Manuel, El Conde Lucanor, Ex. XIV, c. 1335, in (Pato 2002)].

"The Lombard man suffered from a fatal illness, and his friend that he had, when he saw him in death, advised him to confess his sins in Santo Domingo"

b. A las diez preguntas dijo este testigo que sabe lo contenido en ella porque un su hermano se lo dijo [«Información de méritos y servicios de Miguel Sánchez de Guido», CORDE, Costa Rica, 1566].

"To those ten questions this witness said that he knows what is contained in it because his brother told him"

c. E: ¿Ha corrido alguna maratón? I: Yo tengo un mi hijo que tiene como vicio correr y participa en todas las maratones, y yo era su único fanático [«D frente», Francisco M. Martínez, Prensa Libre (Guatemala) 04-10-2004].

"E: Have you ever run a marathon? I: I have my son whose vice is to run and participates in all marathons, and I was his only fan"

d. Soñaba el entierro de mi abuelito, y que cuando abrían el cajón no era mi abuelito el que estaba, era un mi tío, en realidad fue el que se murió después ... [Belizean Spanish, English and Creole Corpus, M-35, West, in (Fuller Medina 2016)].

"I dreamed my grandfather's funeral, and when they opened the drawer it was not my grandfather who was in it, it was my uncle, actually he was the one who later died ... "

\subsection{Iterative Value}

The construction also holds an iterative or habitual value. In this case the information is known and shared by the speaker and the hearer (García Tesoro 2002; Palacios Alcaine 2004; Pato 2002). The possessive relationship is established by the possessive, not by the context. It appears with [-animate] nouns in Central America varieties (cf. 2a-b Guatemala):

(2) a. Clemente siempre andaba con los huesos de su hijo en una su bolsa [H-20, ladino, monolingüe, in (Pato 1999, 2002)].

"Clemente was always with the bones of his son in his bag"

b. «El caso de un fantasma (espanto) que regala dinero». Pues eh ... dicen que antes, por allí por la ... por allí por los Ucaliptos, era la ... el lugar donde tenía [el espanto] un su sitiecito [C. A. Lara Figueroa, Cuentos y consejas populares de Guatemala, 1990, p. 70, in (Palacios Alcaine 2004)].

"The case of a ghost (fear) that gives money away'. Well, uh ... they say that earlier, over there by the ... over there by the Eucalyptus, that was the ... the place where it [the ghost] had its place" 


\subsection{Emphatic Value}

The emphatic, enhancement or intensifier values of the construction are used in order to indicate related or important concepts (Company Company, Concepción 2005, 2009; García Tesoro 2002; Nieuwenhuijsen 2005, 2007; Palacios Alcaine 2004; Pato 2002). It is also used for marking decreasing size ('smallness or insignificance') and affectivity (Martin 1985; Pato 2002). The presence of the diminutive favors the construction (Nieuwenhuijsen 2007). It is habitually attested with [-animate] and [+countable] nouns. It conveys pragmatic, quantitative or qualitative information (Palacios Alcaine 2004), as we see in South Mexico and Central America varieties (cf. 3a Chiapas, 3b Guatemala):

(3) a. A don Límbano le encargamos unos nuestros cotorritos, cuando tengan cría los que compró, que nos tome en cuenta porque nos gusta mucho los pajaritos [«Las Comadres». Diario de Comitán (Chiapas, México), 06-09-2005].

"We ask Don Límbano for a few small parrots, when the birds that he bought breed, he should take us into account because we love little birds"

b. El papá ... este ... le regaló unos centavos al niño pobre y la mamá le regaló unos sus centavos al niño rico. Agarraron camino ... Pero en eso el rico le dice: -Mirá, yo cargo bastante dinero. -Yo no tengo, contestó el pobre ... [C. A. Lara Figueroa, Cuentos populares de encantos y sortilegios en Guatemala, 1992, p. 67, in (Palacios Alcaine 2004)].

"The dad ... mm ... he gave some pennies to the poor kid and the mother gave a few cents to the rich kid. They started their way ... But the rich kid says: -Look, I carry enough money. -I do not have any, answered the poor kid ..."

\subsection{Discursive-Pragmatic Value}

The discursive pragmatic value of the construction is attested in narrations, tales and also in the opinion section (such as letters/messages from hearers or readers) of mass media. It marks special relevance and acts as discursive focus (Palacios Alcaine 2004). It presents important entities that have referential persistence throughout the narration (Company Company, Concepción 2005). It is attested with any kind of noun, and it has no semantic restrictions in Central America varieties (cf. $4 a-c$ Guatemala). The nuance of 'affectivity' may be maintained. The main problem with this value lies in how to differentiate the kind of context in which it appears, a key feature for the aim of 'un su amigo' exaptation. The referential persistence mentioned is also an important contextual feature (cf. $4 c$, nonliterary example).

(4) a. Ella que iba a preguntar a una casita que había allí con una su ventanita, cuando vio por la ventana, estaba el príncipe. Pero él le dijo que si ella no entraba por la ventana entonces no lo volvería a ver nunca, entonces ella saltó la ventana y allí agarró al príncipe y se abrazaron y vivieron felices [C. A. Lara Figueroa, Cuentos populares de encantos y sortilegios en Guatemala, 1992, p. 37, in (Palacios Alcaine 2004)].

"She was going to ask [something] in a little house that was over there, with its window, when she saw through the window that the prince was there. But he told her that if she did not come through the window then she would not see him ever again, so she jumped through the window and grabbed the prince and they hugged and they lived happily"

b. Eran muy pobres, tenían una su vaquita que ordeñaban ... $\mathrm{m}$... d'eso vivían, de su lechita [C. A. Lara Figueroa, Cuentos populares de encantos y sortilegios en Guatemala, 1992, p. 130, in (Palacios Alcaine 2004)].

"They were very poor, they had a cow that they milked ... m ... they made a living out of that, of its milk" 
c. No será, Don Estuardo, que usted lo que busca es un su puestecito en el gobierno, por eso habla mucho, por eso anda criticando todo, por eso critica a la misma 'cobardía chapina'. Tenga cuidado, no hable mucho, porque lo van a acusar de a saber ni qué, y usted está patojo. Si en Guatemala las cosas no van a cambiar, hombre [Estuardo Zapeta, «iViva la cobardía chapina!», La Hora (Guatemala), 21-04-2003].

"It would not be, Don Estuardo, that you are looking for a small position in the government, that's why you talk so much, why you criticize everything, why you criticize the 'Chapina cowardice'. Be careful, do not talk a lot, because they will accuse you of who knows why, and you are still a kiddy. Things are not going to change in Guatemala, man"

As we saw in previous examples, the structure acquires another nuance (a connotative nuance), far beyond its literal meaning. Such a new meaning depends on the actual context and triggers various pragmatic inferences, a discourse-pragmatic value. That is why previous knowledge of the situation is required to foster its discursive processing. Among the variables determining the environment of discourse the following have been singled out: text organization, source of information, attitudes of the speaker (subjectivity), speaker-hearer interactions (intersubjectivity), situation of discourse, and world knowledge (cf. for example Kaltenböck et al. 2011). A discussion which I reserve for future research cf. (Pato 2015).

\section{Final Considerations and Conclusions}

The construction under analysis can be explained thanks to grammaticalization theory. Opaque (and obsolete) grammatical material, which cannot be spontaneously understood, might be reused for new purposes in new varieties as phenomena of the narrative discourse (Van Dijk and Kintsch 1983). The possessive construction considered here is associated to structures of focus and topic-the construction marks also a discursive topic (Company Company, Concepción 2005; Pato 2015).

In refunctionalization processes, the speakers create a grammatical model where there was previously none. The construction gets to convey a (new) value (see examples in 4), different from the one it used to have in other stages of the evolution of the language (see examples in 1 to 3) (Harris and Campbell 1995; Willis 2010). The new values do not arise from the properties of the old ones: it is not a matter of acquisition and adaptation of the old system, rather, a new system is being created (Willis 2016).

Exaptation is not necessarily deemed to contribute to create a new function in the system-what is important is that there is a new function of the opaque (and obsolete) trait in the process of exaptation (Willis 2010, 2016).

On the other hand, polyfunctionality of contexts and constructionalization (Traugott and Trousdale 2014) also have a role in the process. The forms ('un + su') maintain their basic meaning, although in certain cases the possessive may not be necessary; polysemy lies within the contexts (what is meant in specific contexts), so the locus of this grammatical change would be the context. That is to say, the value of the construction is inferred from the discursive context. Therefore, we are faced by a change triggered by specific contextual use.

Funding: This research received no external funding.

Conflicts of Interest: The author declares no conflicts of interest.

\section{References}

Brinton, Laura, and Dieter Stein. 1995. Functional renewal. In Historical Linguistics 1993: Selected Papers from the 11th International Conference on Historical Linguistics (= Current Issues in Linguistic Theory, 124). Edited by Henning Andersen. Amsterdam and Philadelphia: John Benjamins, pp. 33-47.

Carlson, Robert, and Doris Payne. 1989. Genitive Classifiers. In Proceedings of the Fourth Meeting of the Pacific Linguistic Conference (= Pacific Linguistics Conference, 4). Edited by Robert Carlson, Scott DeLancey, Spike Gildea, Doris Payne and Anju Saxena. Eugene: University of Oregon, pp. 87-119. 
Company Company, Concepción. 1995. Cantidad vs. cualidad en el contacto de lenguas. Una incursión metodológica en los posesivos 'redundantes' del español Americano. Nueva Revista de Filología Hispánica 43: 305-39.

Company Company, Concepción. 2005. Frecuencia de uso y contacto lingüístico en sintaxis. Artículo indefinido + posesivo en el español americano. Spanish in Context 2: 131-56.

Company Company, Concepción. 2009. Artículo + posesivo + sustantivo y estructuras afines. In Sintaxis histórica de la lengua española. Segunda Parte: La frase nominal. Edited by Company Company, Concepción. Mexico City: Fondo de Cultura Económica \& Universidad Nacional Autónoma de México, vol. I, pp. 759-880.

Croft, William. 2000. Explaining Language Change: An Evolutionary Approach. Harlow: Longman.

Elsig, Martin. 2015. La posesión atributiva en el español centroamericano: Variantes y funciones. Paper presented at the XX Congreso de la Asociación Alemana de Hispanistas 2015/20, Deutscher Hispanistentag, Heidelberg, Germany, March 18-22.

Fuller Medina, Nicté. 2016. Language Mixing in Northern and Western Belize: A Comparative Variationist Approach. Ph.D. Thesis, University of Ottawa, Ottawa, ON, Canada.

García Tesoro, Ana Isabel. 2002. El español en contacto con lenguas mayas: Guatemala. In El Indigenismo Americano III. Actas de las Terceras Jornadas sobre Indigenismo Americano. Edited by Azucena Palacios and Ana Isabel García. Valéncia: Universitat de Valéncia, pp. 31-58.

García Tesoro, Ana Isabel. 2011. Cada quien tiene un su nagual'. La construcción artículo indefinido + posesivo + nombre en el español de Guatemala. The Journal of the Faculty of Foreign Studies 43: 197-209.

Giacalone Ramat, Anna, and Paul J. Hopper. 1998. Introduction. In The Limits of Grammaticalization (= Typological Studies in Language, 37). Edited by Anna Giacalone Ramat and Paul J. Hopper. Amsterdam and Philadelphia: John Benjamins, pp. 1-11.

Greenberg, Joseph H. 1991. The last stages of grammatical elements: Contractive and expansive desemanticization. In Approaches to Grammaticalization (= Typological Studies in Language, 19.1). Edited by Elizabeth Closs Traugott and Bernd Heine. Amsterdam and Philadelphia: John Benjamins, vol. I, pp. 301-14.

Harris, Alice C., and Lyle Campbell. 1995. Historical Syntax in Cross-Linguistic Perspective. Cambridge: Cambridge University Press.

Heine, Bernd. 2003. On degrammaticalization. In Historical Linguistics 2001: Selected Papers from the 15th International Conference on Historical Linguistics (= Current Issues in Linguistic Theory, 237). Edited by Barry J. Blake and Kate Burridge. Amsterdam and Philadelphia: John Benjamins, pp. 163-79.

Kaltenböck, Gunther, Bernd Heine, and Tania Kuteva. 2011. On thetical grammar. Studies in Language 35: 852-97. [CrossRef]

Keniston, Hayward. 1937. The Syntax of Castilian Prose: The Sixteenth Century. Chicago: The University of Chicago Press.

Lass, Roger. 1990. How to do things with junk: Exaptation in language evolution. Journal of Linguistics 26: 79-102. [CrossRef]

Lass, Roger. 1997. Historical Linguistics and Language Change. Cambridge: Cambridge University Press.

Martin, Laura. 1985. Una mi tacita de café: The Indefinite Article in Guatemalan Spanish. Hispania 68: $383-87$. [CrossRef]

Narrog, Heiko. 2007. Exaptation, Grammaticalization, and Reanalysis. California Linguistics Notes 32: 1-24.

Nieuwenhuijsen, Dorien. 2005. Diacronía y diatopía de las construcciones posesivas. Estudios de Lingüística del Español 22: 1-10.

Nieuwenhuijsen, Dorien. 2007. Un amigo suyo se enfrenta con un su amigo. El uso de dos construcciones posesivas en dos periódicos de Guatemala y México. Nueva Revista de Filología Hispánica 55: 321-50.

Norde, Muriel. 2002. The final stages of grammaticalization: Affixhood and beyond. In New reflections on grammaticalization (= Typological Studies in Language, 49). Edited by Ilse Wischer and Gabriele Diewald. Amsterdam and Philadelphia: John Benjamins, pp. 45-65.

Norde, Muriel. 2009. Degrammaticalization. Oxford: Oxford University Press.

Palacios Alcaine, Azucena. 2004. El valor discursivo en las construcciones de artículo indefinido + posesivo + nombre en el español de Centroamérica. Signo y Seña 13: 185-214.

Pato, Enrique. 1999. Sobre el artículo con posesivo en español medieval. Unpublished manuscript.

Pato, Enrique. 2002. La estructura posesiva una mi amiga en el español de Guatemala. In El Indigenismo Americano III. Actas de las Terceras Jornadas sobre Indigenismo Americano.. Edited by Azucena Palacios and Ana Isabel García. Valéncia: Universitat de Valéncia, pp. 121-54. 
Pato, Enrique. 2015. El posesivo (antepuesto) tónico en español: ¿fenómeno de foco y contraste? Dialectologia 14: $47-73$.

Pountain, Christopher J. 2000. Capitalization. In Historical Linguistics 1995, Volume 1: General Issues and non-Germanic Languages (= Current Issues in Linguistic Theory, 161). Edited by John Charles Smith and Delia Bentley. Amsterdam and Philadelphia: John Benjamins, vol. I, pp. 295-309.

Seiler, Hansjakob. 1983. Possession, as an Operational Dimension of Language. Tübingen: Narr Verlag.

Serradilla Castaño, Ana. 2007. Sobre la evolución del artículo + posesivo en el español peninsular: causas de su pervivencia y comparación con la situación del español americano. In Actes du XXIV Congrès International de Linguistique et Philologie Romanes. Edited by David Trotter. Tübingen: Max Niemeyer, vol. II, pp. 319-30.

Silva Ceceña, Rosaura. 2005. La construcción artículo indefinido + posesivo + sustantivo en el español antiguo. Estructura y diacronía. Bachelor's thesis, Universidad Nacional Autónoma de México, Ciudad de México, México.

Smith, John C. 2011. Change and continuity in form-function relationships. In The Cambridge History of the Romance Languages, Volume 1, Structures. Edited by Martin Maiden, John Charles Smith and Adam Ledgeway. Cambridge: Cambrigde University Press, pp. 268-317.

Traugott, Elizabeth Closs. 2004. Exaptation and Grammaticalization. In Linguistic Studies Based on Corpora. Edited by Minoji Akimoto. Tokyo: Hituzi Syobo Publishing, pp. 133-56.

Traugott, Elizabeth Closs, and Graeme Trousdale. 2014. Constructionalization and Constructional Changes. Oxford: Oxford University Press.

Van Dijk, Teun A., and Walter Kintsch. 1983. Strategies of Discourse Comprehension. New York: Academic Press.

Vincent, Nigel. 1995. Exaptation and grammaticalization. In Historical Linguistics 1993: Selected Papers from the 11th International Conference on Historical Linguistics (= Current Issues in Linguistic Theory, 124). Edited by Henning Andersen. Amsterdam and Philadelphia: John Benjamins, pp. 433-45.

Willis, David. 2010. Degrammaticalization and obsolescent morphology: Evidence from Slavonic. In Grammaticalization: Current views and issues (= Studies in Language Companion Series, 119). Edited by Ekaterini Stathi, Elke Gehweiler and Ekkehard König. Amsterdam and Philadelphia: John Benjamins, pp. 151-78.

Willis, David. 2016. Exaptation and degrammaticalization within an acquisition-based model of abductive reanalysis. In Exaptation in Language Change (= Current Issues in Linguistic Theory, 336). Edited by Muriel Norde and Freek Van de Velde. Amsterdam and Philadelphia: John Benjamins, pp. 197-225.

(C) 2018 by the author. Licensee MDPI, Basel, Switzerland. This article is an open access article distributed under the terms and conditions of the Creative Commons Attribution (CC BY) license (http:/ / creativecommons.org/licenses/by/4.0/). 